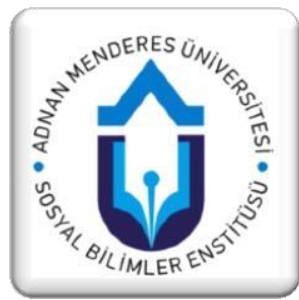

\title{
Orta Asya Bir "Bölgesel Güvenlik Kompleksi” Olarak Tanımlanabilir Mi?
}

\author{
Caner AKKAYA 1
}

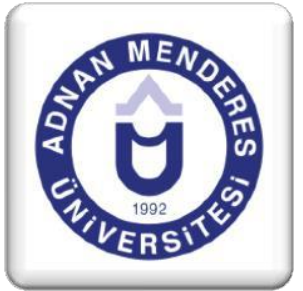

Özet

Uluslararası ilişkiler kapsamında en önemli sorunlardan bir tanesi aktörlerin güvenlik kaygısını nasıl bertaraf edebileceğidir. Bu bağlamda; Kopenhag Okulu "Güvenlikleştirme”, “Güvenlik Sektörleri” ve "Bölgesel Güvenlik Kompleksi” yaklaşımları ile güvenlik çalışmalarına katkı sağlamaktadır. Kopenhag Okulu'nun çalışmalarında "Bölgesel Güvenlik Yaklaşımı" çerçevesinde dünyanın çeşitli bölgesel güvenlik komplekslerine ayrıldığı görülmektedir. Bu komplekslerden bir tanesi "Sovyet Sonrası Coğrafya" olarak tanımlanmaktadır. Dolayısıyla Orta Asya, Kopenhag Okulu çalışmalarında "Sovyet Sonrası Coğrafya" kapsamında ele alınmakta ve "Alt Kompleks" olarak tanımlanmaktadır. Bu makalede, Kopenhag Okulu'nun "Sovyet Sonrası Coğrafya Bölgesel Güvenlik Kompleksi” ile farklılıklar içeren oldukça geniş bir coğrafyayı işaret ettiği savunulmaktadır. Bu bağlamda; diğer çalışmalardan farklı olarak, makale "Orta Asya ortak değerler ve ortak güvenlik anlayış1 nedeniyle bağımsız bir bölgesel güvenlik kompleksi olarak tanımlanabilir mi?” sorusuna cevap aramaktadır. Bu çerçevede, makale bölgenin ortak hareket kabiliyetinin gelişmesi için öneriler sunmaktadır. Böylelikle, makale güvenlik çalışmaları ve Orta Asya çalışmaları için katkı sağlanmayı amaçlanmaktadır.

Anahtar Kelimeler: Güvenlik, Kopenhag Okulu, Orta Asya, Bölgesel Güvenlik Kompleksi, Güvenlikleştirme. Jel Kodları: F50, F52, F55.

\section{Can Central Asia Be Defined as a "Regional Security Complex"?}

\begin{abstract}
One of the most important problems within the scope of international relations is how can actors eliminate their security concerns? In this context, Copenhagen School contributes to security studies with approaches which are "Securitization", "Sectors of Security" and "Regional Security Complex". In the studies of Copenhagen School, it is seen that World is divided into various regional security complexes in the frame of "Security Complex Approach". One of these complexes is identified as "Post-Soviet Geography". Hence, Central Asia analyzed within the scope of "Post-Soviet Geography" and defined as "Sub-Complex" in the studies of Copenhagen School. In this article, it is defended that Copenhagen School indicates to the pretty extensive area, which includes differences, with "Post-Soviet Geography Security Complex". In this context, the article looks for an answer to this question that "Can Central Asia be defined as an independent regional security complex because of its common values and common sense of security?" as a difference from the others. In this frame, the article offers suggestions for development to common actions of the region. In this way, the article aims to contribute to security studies and Central Asia studies.
\end{abstract}

Keywords: Security, Copenhagen School, Central Asia, Regional Security Complex, Securitization.

Jel Codes: F50, F52, F55.

\footnotetext{
${ }^{1}$ Doktora Adayı, Anadolu Üniversitesi, canerakkaya@ anadolu.edu.tr, ORCID: 0000000241951545.
} 


\section{Giris}

Uluslararası ilişkiler disiplininin incelediği en büyük sorunlardan bir tanesi, başta devletler olmak üzere aktörlerin güvenlik kaygısı ve bu kaygının nasıl bertaraf edilebileceği ile ilgilidir. Bu bağlamda; güvenlik konusu, tarihsel süreçte siyaset bilimi ve uluslararası ilişkiler kapsamında ele alınan önemli konulardan bir tanesi olmuştur. 20. Yüzyıl'dan itibaren güvenlik çalışmalarının içeriğini belirleyen gelişmeler ise dünya savaşları ve ardından gelen Soğuk Savaş dönemi olmuştur. 1930-1985 yılları arasında, özellikle Soğuk Savaş döneminde uluslararası siyasetin gündemi gereği, güvenlik çalışmalarında hakim bakış açısı geleneksel realizm olmuştur. Dolayısıyla nükleer silahların kullanımı, caydırıcılık, misilleme, çatışma çözümü vb. konuların gündemde olması güvenlik çalışmalarının devlet merkezli ve askeri güç kullanımına yönelik olarak şekillenmesi sonucunu doğurmuştur (Akgül Açıkmeşe, 2018: 246). Bahsi geçen dönemde geleneksel realist bakış açısından farklı çalışmalar ortaya konulsa da bu çalışmalarda niteliksel ve niceliksel bir artı̧̧ ancak Soğuk Savaş sonrasında yaşanmıştır. Bir başka ifadeyle; realist bakış açısından farklı bir seçenek sunan eleştirel bakış açıları Soğuk Savaş sonrası dönemde yükselişe geçmiştir.

Kopenhag Okulu, realist bakış açısının güvenlik meselelerini inceleme ve çözüm üretme konusunda yetersiz kaldığını vurgulayan eleştirel çalışma okullarından bir tanesidir. $\mathrm{Bu}$ bağlamda; güvenlik çalışmalarına "Güvenlikleştirme", "Güvenlik Sektörleri" ve "Bölgesel Güvenlik Kompleksi” yaklaşımları ile katkı sağlamaktadır. Güvenlikleştirme, bir meselenin söz edimi aracıllğıyla güvenlik meselesi olarak öne sürülmesi, bu yönde eylemde bulunma girişimi ve belli bir grup tarafindan meselenin güvenlik meselesi olduğu yönünde kabul görmesiyle ilgilidir. Bununla bağlantılı olarak; güvenlik meseleleri sadece askeri sektör bağlamında değil, fakat aynı zamanda siyasal, ekonomik, toplumsal ve çevresel sektör olarak ayrı ayrı tasnif edilmektedir. Bölgesel güvenlik kompleksi ise öncelikle coğrafi yakınlığı ve ortak değerleri bulunan aktörlerin oluşturabileceği bir kompleks olarak tarif edilmektedir. Aynı zamanda herhangi bir bölgenin bölgesel güvenlik kompleksi olarak tanımlanabilmesi için birincil şart, bölge devletlerinin herhangi bir meseleyi güvenlikleştirme konusunda ortak irade göstermesidir. Kopenhag Okulu, çalışmalarında dünyayı farklı bölgesel güvenlik komplekslerine ayırmaktadır. Bunlardan bir tanesi Sovyet sonrası coğrafya olarak tarif edilmektedir (Buzan, 1983; Buzan ve Wæver, 2003; Buzan, Wæver ve Wilde, 1998). Bu bağlamda; Orta Asya (Central Asia), Sovyet sonrası coğrafya kapsamında ele alınmakta ve "Alt Kompleks" olarak değerlendirmektedir.

$\mathrm{Bu}$ çalışmada, Kopenhag Okulu'nun, "Sovyet Sonrası Coğrafya Bölgesel Güvenlik Kompleksi" ile oldukça geniş ve farklılıklar içeren bir coğrafyayı işaret ettiği savunulmaktadır. Bu bağlamda; diğer çalışmalardan farklı olarak "Orta Asya ortak değerler ve ortak güvenlik anlayışı nedeniyle bağımsız bir bölgesel güvenlik kompleksi olabilir mi?" sorusuna cevap aranmaktadır. Dolayısıyla, Orta Asya devletlerinin hangi ortak değerlere sahip olduğu ve ortak güvenlik anlayışını ne derece oluşturabildikleri tespit edilmektedir. Bahsi geçen devletlerin ortak geçmiş, ortak kültür, benzer sosyo-ekonomik yapılar vb. konular üzerinde ortak değerlere sahip oldukları görülmektedir. Ancak ortak güvenlik algısı konusunda zayıf bir birliktelik oluşturmaktadırlar. Bölgede su sorunu, etnik sorunlar, aşırı dinsel gruplar gibi belli başlı konular üzerinde anlaşmazlıklar mevcuttur. Fakat bu konuların bölge devletlerinin bağımsız olduğu 1991 yılından bu zamana büyük ölçekli çatışmalara neden olmadığ 1 gibi zaman içinde önemini yitirdiği görülmektedir. Bir başka ifadeyle; ortak güvenlik bilinciyle bir araya gelinmesi durumunda çözülmesi muhtemel sorunlar olarak nitelendirmek mümkündür. Bu bağlamda; Orta Asya'da ortak güvenlik bilincinin nasıl oluşturulacağı sorusu cevaplanmaktadır. Orta Asya'nın bölgesel güvenlik kompleksi olabilmesi için bölge devletlerini bir arada olmaya teşvik edecek bir ya da birden çok 
"Bölgesel Güç” ihtiyacı olduğu açıktır. Çünkü bölgesel güç, mahiyeti gereği, bulunduğu bölgeyi ortak değerler üzerinden ortak politikalar oluşturma konusunda ikna etmek, bölgeyi ve bölgeyle ilgili olarak uluslararası ilişkilere konu herhangi bir meseleyi küresel düzlemde tartışmaya açmak ya da bölgeyi uluslararası alanda temsil etmek gibi özelliklere sahiptir. Dolayısıyla, Orta Asya'da bir "Bölgesel Güç" varlı̆ğ, ortak güvenlik konusunda bölgesel bilincin oluşmasına önemli katkılar sağlayabilmektedir. ${ }^{2}$ Ayrıca bağımsız bölgesel kalkınma programları bölgenin siyasal ve ekonomik anlamda daha bağımsız olmasını sağlayacaktır. $\mathrm{Bu}$ durum ise güvenlik meselelerinde bölge içinde bağımsız iken bölge dışında ortak hareket edebilmelerini mümkün k1lacaktır.

Bahsi geçen sorulardan hareketle, çalışmada öncelikle güvenlik çalışmalarının gelişimi hakkında bilgiler verilmektedir. Bir sonraki başlıkta, güvenlik çalışmalarına eleştirel bir bakış açısı sunan Kopenhag Okulu'nun güvenlik meselesini nasıl ele aldığı üzerinde durulmaktadır. $\mathrm{Bu}$ bağlamda; "Güvenlikleștirme", "Güvenlik Sektörleri”" ve "Bölgesel Güvenlik Kompleksi" yaklaşımları detaylandırılmaktadır. Bir diğer başlıkta ise Orta Asya'nın, Kopenhag Okulu'nun geliştirdiği bir yaklaşım olarak "Bölgesel Güvenlik Kompleksi" bağlamında değerlendirilmesi sunulmaktadır. Sonuç bölümünde ise çalışmadan elde edilen çıktılar paylaşılmaktadır.

\section{Güvenlik Çalışmaları ve Kopenhag Okulu}

Uluslararası düzende Soğuk Savaş’ın bitmesine ve küreselleşmenin gündeme gelmesine paralel olarak uluslararası siyasetin de farklılaştığı görülmektedir. Bu farklılaşma 1990'lı yılların başından itibaren güvenlik çalışmalarında geleneksel anlayışa eleştirel bakış şeklinde yansımaktadır. Geleneksel güvenlik anlayışını eleştiren araştırmacılar, bu anlayışın dünyadaki güvensizlikleri yansıtmak ve çözüm önermekte yetersiz kaldığı fikrinden hareketle eleştirilerini somutlaştırmaktadır. Dolayısıyla bu araştırmacılar güvenliğin sadece askeri olarak algılanması, güvenlik uygulamalarının da sadece savaşı önlemek üzere kurulu olmasını eleştirmektedir. Eleştirel bakış açısıyla güvenlik, sadece fiziksel şiddetin önlenmesini değil fakat aynı zamanda insanların mutluluğunun ve refahının sağlanması da kapsayan bir anlam ifade etmektedir. (Bilgin, 2010: 32) Bu noktada, güvenlik çalışmalarında realist bakış açısını hakim olmasını yetersiz bulan eleştirel görüşlerden bir tanesi "Kopenhag Okulu” olarak bilinen ekoldür. Kopenhag Okulu, 1985'te Kopenhag Üniversitesi bünyesinde

\footnotetext{
${ }^{2}$ Uluslararası ilişkiler disiplininde "Bölgesel Güç" kavramı, genellikle "Orta Büyüklükte Güç” kavramı ile karıştırılmaktadır. "Orta Büyüklükte Güç” özelliği gösteren devletlerin, askeri ve ekonomik kapasiteleri ve küresel meseleleri etkileme düzeyleri dikkate alınarak tespit edildiği bilinmektedir. "Bölgesel Güç" kavramı kimi çalışmalarda "Bölgesel Lider" (Flemes, 2010) ya da "Bölgesel Büyük Güç" (Neumann, 1992) şeklinde ele alınabilmektedir. "Bölgesel Güç" kavramının içeriğine yönelik yapılan çalışmalar incelendiğinde bir devletin bölgesel güç olabilmesi için kapasite ve etkileme yeteneğinden daha fazlası gerektiği sonucuna ulaşılmaktadır. Buna göre; bir devlet bölgesel güç olabilmek için öncelikle bir bölgeye aidiyet bağıyla bağlı olmak, bölgesel güç olmaya yönelik iddialar ortaya koymak, bu iddiaları destekleyecek kapasiteye sahip olmak ve son olarak gerek bulunduğu bölgedeki diğer devletlerin gerekse büyük güçlerin nazarında bölgesel güç olarak kabul görmek şeklinde temel ön şartları yerine getirmek durumundadır. Örneğin; Brezilya'nın "Bölgesel Güç" bağlamında ele alındığı çalışmalar incelendiğinde bahsi geçen ön şartları sağladığı ve dolayısıyla Güney Amerika Bölgesi'nde bir bölgesel güç olduğu görülmektedir (Lima ve Hirst, 2006: 21-40; Spektor, 2009: 1-4). Fakat İsrail'e yönelik benzer bir inceleme yapıldığında özellikle bölge devletleri tarafından kabul görmeye yönelik ön şartı yerine getirmekte zorlandığı görülmektedir (Beck, 2010: 136; Kappel, 2014). Benzer șekilde, Orta Asya devletlerinden Kazakistan'ın "Bölgesel Güç" bağlamında incelendiği çalışmada, Kazakistan'ın gerek bölge devletlerinden gerekse küresel büyük güçlerden bölgesel güç olmak yönünde bir kabul görmediği, bu nedenle bölgesel güç olarak tanımlanamayacağı tespit edilmiştir (Akkaya, 2018). Bu bilgilerden hareketle, bir bölgenin "Bölgesel Güvenlik Kompleksi" olarak tanımlanmasında "Bölgesel Güç" unsuru, en azından mevcut durumu bir adım ileri taşımak açısından önem arz etmektedir. "Bölgesel Güç" kavramı ve bazı devletlerin bahsi geçen kavram bağlamında incelendiği çalışmalar için yukarıda verilenlere ek olarak bkz. (Flemes, 2007; Hurrell, 2005; Nel ve Nolte, 2010; Nolte, 2010).
} 
kurulun "Barıș ve Çatışma Araștırma Merkezi"nde Avrupa Güvenliği çalıșma grubunun "Avrupa Güvenliği’nin Askeri-Olmayan Boyutları" başlıklı projeyi hayata geçirmesi sonucunda kurulmuştur (Akgül Açıkmeşe, 2018: 251) Bu bağlamda; okulun güvenlik alanındaki çalışmaları, Barry Buzan ve Olé Wæver'ın çalışmalarını merkeze alarak şekillenmiştir (Mcdonald, 2008: 68). Dolayısıyla, "Bu tarihten itibaren, özellikle okulun belkemiği Barry Buzan ve Olé Wæver Kopenhag Okulu'nun özünü oluşturan üç ana yaklaşımı -güvenlikleştirme, sektörel analiz ve bölgesel güvenlik kompleksleri- ortaklaşa çalışmalarında geliştirmişlerdir.” (Akgül Açıkmeşe, 2018: 251). Gelinen noktada, Kopenhag Okulu'nun güvenlik konusundaki düşüncelerini Orta Asya özelinde değerlendirebilmek için bahsi geçen üç yaklaşımı ana hatlarıyla incelemek gerekmektedir.

\subsection{Kopenhag Okulu'nda Güvenlikleștirme Yaklaşımı}

"Güvenlikleştirme" kavramı ilk olarak 1995'te Olé Wæver tarafından ortaya atılmış (Baysal ve Lüleci, 2015: 71), daha sonra Kopenhag Okulu tarafından çeşitli çalışmalarda ele alınarak geliştirilmiştir. Wæver (1995), çalışmasında güvenlikleştirmeyi bir söz edimi (speech act) olarak tartışmaktadır. Bu bağlamda; güvenlikleştirme ve güvenliksizleştirme dört ana soruya verilen cevaplara bağlı olarak tarif edilmektedir. Bunlardan ilki; karar vericilerin sorunları ve gelişmeleri ne zaman, nasıl ve neden güvenlik meselesi olarak gördükleri yani güvenlikleştirdikleriyle ilgilidir. İkincisi; bu tür bir çabada ne zaman, nasıl ve neden başarılı ya da başarısız olunduğunu sorgulamaktadır. Üçüncüsü; diğer grupların güvenlikleştirmeyi gündeme getirmek için ne tür girişimlerde bulunduklarını anlamaya yöneliktir. Dördüncüsü ise meselelerin güvenlik gündeminin dışında tutulmasına ya da güvenlik gündemine dahil edilmesine yönelik girişimleri tespit etmenin mümkün olup olmadığını anlamaya çalışır. Dolayısıyla, bir konu karar vericiler tarafından "güvenlik" olarak adlandırıldığı takdirde güvenlikleştirilmektedir. $\mathrm{Bu}$ durum, konunun gerçek bir güvenlik meselesi olup olmadığından bağımsız olarak inşacı bir bakış açısıyla güvenliğin "özneler arası bir yapım" şeklinde tanımlanmasıyla ilgilidir (Baysal ve Lüleci, 2015: 71). Sonuç olarak, başarılı bir güvenlikleştirmenin üç bileşene sahip olması beklenir. Bunlardan ilki, mevcudiyete dair tehditler; ikincisi, tehditlere yönelik acil eylem oluşturma ve üçüncüsü, belirli bir grubu tehdit varlığından kaynaklı harekete geçilmesine yönelik kabulüdür (Buzan, Wæver ve Wilde, 1998: 26). Güvenlikleştirmeye ilişkin dikkat edilmesi gereken noktalardan bir diğeri ise kavramın geniş güvenlik gündemini sakıncalarını ve gereksinimlerini harmanlayan bir yaklaşım olmasıdır (Akgül Açıkmeşe, 2018: 251). Diğer bir ifadeyle; güvenlikleştirme, her konunun güvenlik meselesi olarak öne sürülmesine karşı çıkarken, aynı zamanda realist bakış açısında olduğu gibi dar bir çerçeveyi eksik bulmaktadır.

\subsection{Kopenhag Okulu ve Güvenlik Sektörleri}

Kopenhag Okulu'nun güvenlik çalışmaları bağlamında ortaya koyduğu bir diğer yaklaşım "Güvenlik Sektörleri”dir. Bu bağlamda; Soğuk Savaş boyunca realist bakış açısının ağırlıklı olduğu askeri güvenlik merkezli anlayışın dışında sektörlerin varlığına işaret edilmektedir. Ancak değişen ve gelişen uluslararası siyasete bağlı olarak güvenliğin kapsamı da değişmektedir. Bu durumda güvenlik, askeri güvenlik sektörünün yanı sıra siyasi, ekonomik, toplumsal ve çevresel sektör olmak üzere beş ana başlık altında incelenebilmektedir. Bir başka ifadeyle; Kopenhag Okulu, güvenliği bahsi geçen beş ana konu çerçevesinde ele almaktadır. Buzan, Wæver ve Wilde’ye göre (1998: 7) her sektör kendine özgü etkileşim modellerine sahiptir. Dolayısıyla askeri sektör etkili zorlama ilişkileriyle; siyasi sektör yetki, yönetim statüsü ve tanınma ilişkileriyle; ekonomik sektör ticaret, üretim ve finans ilişkileriyle; toplumsal sektör kolektif kimlik ilişkileriyle; çevresel sektör ise insan eylemleri ile gezegensel biyosfer arasındaki ilişkilerle ilgilidir. 
$\mathrm{Bu}$ noktada, yukarıda bahsi geçen sektörlerin referans nesnelerinin ne olduğu önem kazanmaktadır. Askeri sektörde, en önemli referans nesnesi devlet iken en önemli güvenlikleştirme aktörü yönetici seçkinlerdir. Fakat bu durum, onların tek referans nesnesi ve özne oldukları anlamına gelmemektedir. Buna rağmen devletin en önemli referans nesnesi olması, devletlerin genellikle en büyük askeri kaynakları yönetmesiyle ilgilidir. Benzer şekilde, yönetici elitler en önemli aktör olması onların süreç içinde hukuksal ve siyasal bağlamda içerde ve dışarda güç kullanımıyla yetkilendirilmiş olmalarından kaynaklanmaktadır. (Buzan, Wæver ve Wilde, 1998: 50) Siyasi sektörde, askeri sektör ile benzerlikler görülse de burada referans nesnesi ve özne günümüz siyasal sistemindeki tüm aktörler olabilir (Buzan, Wæver ve Wilde, 1998: 145). Dolayısıyla askeri sektörden sert güç kullanımı yönüyle farklılaşmaktadır. Ekonomik sektörde; devletlerin yanı sıra sınıflar ya da bireyler gibi somut nesnelere ek olarak küresel ekonomik gibi soyut sistemler de referans nesnesi olabilmektedir (Baysal ve Lüleci; 2015: 73). "Toplumsal sektörde düzenleyici kavram kimliktir. Toplumsal güvensizlik, toplumların bir gelișmeyi ya da potansiyel tehdidi toplumlarına karşı yaşamsal bir mesele olarak görmeleriyle meydana gelmektedir." (Buzan, Wæver ve Wilde, 1998: 120) Dolayısıyla, toplumsal güvenlikte referans nesnesi tanımlanan kimlik üzerinden toplumun kendisidir. Son olarak; çevresel sektörde referans nesnesi yine çevrenin kendisidir. Öznesi ise diğer sektörlerde işaret edilen herhangi bir aktör olabileceği gibi yine doğanın kendisi de çevresel sektörün öznesi halini alabilmektedir. (Buzan, Wæver ve Wilde, 1998: 76-77) Dolayısıyla, çevresel sektörün de diğer sektörler gibi birçok referans nesnesine ve özneye sahip olduğu görülmektedir. Özetle, Kopenhag Okulu herhangi bir özneden herhangi bir nesneye yönelen tehdit ya da tehdit algılarını sınıflandırarak güvenlik çalışmalarına katkı sağlamışlardır. Bu durum ise güvenlik çalışmalarında meselelerin geniş bir bakış açısıyla fakat belirli çerçevelerle incelenmesine zemin hazırlamaktadır.

\subsection{Kopenhag Okulu ve Bölgesel Güvenlik Kompleksi}

Kopenhag Okulu'nun güvenlik çalışmaları kapsamında ortaya koyduğu yaklaşımların üçüncüsü "Bölgesel Güvenlik Kompleksi" yaklaşımıdır. Bölgesel güvenlik kompleksi aynı zamanda bu çalışmanın ana çerçevesini de belirlemektedir. Dolayısıyla bu başlık altında bölgesel güvenlik kompleksi'nin nasıl tanımlandığı, ne anlama geldiği, önkoşullarının neler olduğu gibi sorulara cevap aranmaktadır. Buzan, bölgesel bağlamda bir güvenlik kompleksini, "Temel güvenlik kaygılarıyla birbirine yeteri kadar bağlı ve ulusal güvenlik kaygılarının gerçekçi bir şekilde birbirinden ayrı düşünülemeyeceği bir grup devlet.” (1983: 105-106) olarak tanımlamayı tercih etmektedir. Bu noktada, bir grup devletin hangi bağlantılar üzerinden birbirine bağlı olduğu sorusu önem kazanmaktadır. Buzan'a göre; bir güvenlik kompleksinde bir grup devleti birbirine bağlayan siyasi, coğrafi, ekonomik, tarihi, stratejik ya da kültürel birçok bağlantı noktası bulunabilmektedir. Dolayısıyla, uluslararası sistemde birçok güvenlik kompleksi var olabilmektedir. Ayrıca birçok güvenlik kompleksinin olması durumu, bu komplekslerin belirli noktalarda kesişmesi sonucunu da beraberinde getirmektedir. Bunlara ek olarak; kompleks dışı bir devlet, tanımlanan kompleks içinde önemli bir rol sahibi olabilir. Bu noktada; kompleksin kendisinden ziyade ortak tehdit algıları güvenlik sorunlarının merkezinde yer almaktadır (1983: 106).

Buzan ve Wæver, uluslararası sistemde tüm devletlerin bir dereceye kadar küresel bir güvenlik bağımlılığı ağına girdiğini belirtmektedir. Ancak güvensizliğin boyutu genellikle uzaklık yakınlık ilişkisiyle doğru orantılı olduğu için, bu karşılıklı bağımlılık tekdüze olmaktan uzak bir durumu tarif etmektedir. Bu bağlamda; Anarşi, yakınlık-uzaklık durumu ve coğrafi ayrımlar nedeniyle güvenlik bağımlılığının yoğunlaştığı bölgesel kompleksler oluşmaktadır (2003: 46). Baysal ve Lüleci (2015: 73)'ye göre; Bölgesel Güvenlik Kompleksi bir yaklaşım olarak, ilk ortaya atıldığı yıllarda "güvenlik algıları ve güvenlik kaygıları 
birbirinden bağımsız düșünülemeyen devletler grubu" olarak tanımlanmıștır. Ancak daha sonra Kopenhag Okulu'nun diğer yaklaşımlarıyla birlikte düşünülmüştür. Dolayısıyla "güvenlikleştirme ve güvenlik-dışılaştırma süreçleri birbirinden bağımsız olarak düşünülemeyen birimler" olarak tanımlanır hale gelmiştir.

Sonuç olarak, Kopenhag Okulu'na göre bölgesel güvenlik kompleksinin temel şartlarından bir tanesi, devletlerin birbirleri ile olan coğrafi yakınlığıdır. Buna paralel olarak; devletlerin herhangi bir ya da birçok konu üzerinde ortak değerler paylaşması ve bu değerler üzerinden bölge olarak tarif edilmesi gerekmektedir. Bir diğer önemli nokta, birbirlerini dost ya da düşman olarak algılamalarından ziyade herhangi bir meselenin güvenlikleştirilmesi konusunda ortak görüşe sahip olmalarıdır. Kopenhag Okulu'nun bölgesel güvenlik kompleksi bağlamında tüm tanımları ve açıklamaları bir arada değerlendirildiğinde yaklaşımın geniş bir anlam ifade ettiği görülmektedir. Ancak okul tarafindan, bir bölgenin bölgesel güvenlik kompleksi olarak tanımlanması için neyin aranacağı ve bunların birbirleriyle nasıl ilişkilendirileceği dört madde olarak belirlenmiştir. Buna göre;

1- Bölge devletlerinin her birinin herhangi bir şekilde iç kaynaklı tehdit potansiyelini,

2- Bölgedeki devletlerin birbirleriyle her türlü ilişkilerini,

3- Ele alınan bölgenin diğer bölgelerle etkileşim derecesini,

4- Küresel güçlerin bölgedeki rolünü incelemek gerekmektedir. (Buzan ve Wæver, 2003: 51)

Kopenhag Okulu, geliştirmiş olduğu bölgesel güvenlik tanımları ve inceleme soruları üzerinden dünyayı çeşitli bölgesel güvenlik kompleksleri bağlamında incelemektedir. Örneğin; Kuzey Amerika, Güney Amerika, Avrupa, Ortadoğu, Güney Afrika, Orta Afrika, Güney Asya ve Doğu Asya birer bölgesel güvenlik kompleksi olarak ele alınmıştır. Ayrıca Sovyet sonrası coğrafya da okulun bir bölgesel güvenlik kompleksi olarak incelediği bölgeler arasındadır. Ancak Sovyet sonrası coğrafya oldukça geniş bir alanı kapsamaktadır. Bu bağlamda; Orta Asya'yı içinde barındıran bir bölgesel güvenlik kompleksinden söz edilmektedir. Çalışmanın bundan sonraki bölümünde Orta Asya'nın kendine özgü bir bölgesel güvenlik kompleksi olarak tanımlanıp tanımlanamayacağı tartışılmaktadır.

\section{Orta Asya Bir "Bölgesel Güvenlik Kompleksi”" Olarak Tanımlanabilir Mi?}

Orta Asya Bölgesi, bir bölge olarak birçok çalışmada farklı açılardan ele alınmaktadır. Bu çalışmaların ortak noktası ise bölgenin Kazakistan, Kırgızistan, Türkmenistan, Tacikistan ve Özbekistan devletlerinden oluştuğu konusunda hem fikir olmalarıdır (Akiner, 1997; Roy, 2000; Yapıc1, 2004; Brzezinski, 2005; Purtaş, 2008). Ancak bunun da ötesinde, bahsi geçen devletlerin kendisini nasıl tanımladığı önemlidir. $\mathrm{Bu}$ bağlamda; Sovyet Sosyalist Cumhuriyetler Birliği (SSCB)'nin dağılmasıyla birlikte kurulan devletler kendilerini Orta Asya devletleri olarak tanımlamıştır (Aydın, 2004: 367; Akkaya, 2018: 20). Buna paralel olarak; Kopenhag Okulu'nun ileri gelen araştırmacilarından Buzan ve Wæver da Orta Asya'nın bahsi geçen beş devletten oluştuğu konusunda birleşmekte ve çalışmalarında bu şekilde yer vermektedir (Buzan ve Wæver, 2003: 423). Dolayısıyla Özbekistan, Tacikistan, Türkmenistan, Kırgızistan ve Kazakistan devletlerinden oluşan Orta Asya bölgesinin bölgesel güvenlik kompleksi bağlamında incelenmesi mümkündür. Çünkü bahsi geçen devletler coğrafi yakınlıklarının yanı sıra ortak tarihsel geçmiş, birbirleri arasında heterojen nüfus, benzer kültürler ve sosyolojik yapı, benzer ekonomiler gibi ortak değerlere sahiptir.

Kopenhag Okulu, Orta Asya'yı bölgesel güvenlik meseleleri açısından oldukça "kalabalık" gündeme sahip bir bölge olarak tanımlamaktadır. Öyle ki her bir devlet yerel bağlamda oldukça hassas bir yapıya sahiptir. Bu noktada; en önemli sorunlardan bir tanesi, etnik iç içe geçmişlik dolayısıyla yaşanan yerel ve bölgesel gerilimlerdir. Bu çatışmalardan bazılarına 
örnek vermek gerekirse, 2005 yılında Özbekistan'ın Kırgızistan sınırında Fergana Vadisi olarak tanımlanan bölgede bulunan Andican şehrinde "radikal İslamcı" olarak tarif edilen gruplar ile Özbekistan kolluk kuvvetleri arasında gerçekleşen çatışmaların, dönemin Özbekistan Cumhurbaşkanı İslam Kerimov tarafından şiddetle bastırılması Orta Asya'da gerilimi yükselten meseleler arasında gösterilmektedir (DW.COM, 2005). Yaklaşık 700 sivilin öldüğü çatışmalarda, uluslararası alanda dikkat çekmiştir (Aydın, 2017: 473). Olayların, "radikal Müslüman grupların faaliyet gösterdiği en önemli bölgelerden biri" (DW.COM, 2005) olarak tanımlanan Fergana Vadisi'nde gerçekleşmesi, bölgesel güvenliğin sürekli tehdit edildiği bir alan olması açısından önemlidir. Ancak Orta Asya devletlerinin bölgede yaşanan "radikal İslam" tehdidine karşı ortak bir güvenlikleştirme yönünde politika sergilediklerinin belirtmek mümkün değildir. Bölgede etnik temelli bir başka çatışma örneği, Kırgızistan ile Tacikistan arasında 2010 yılından günümüze süregelmektedir. İki devlet arasındaki 472 kilometrelik sınır boyunca iç içe geçmiş Kırgız ve Tacik halk arasında genellikle su kullanımı, yol kullanımı ve inşaat projeleri üzerinden meydana gelen anlaşmazlıklar özünde etnik temelli anlaşmazlıklardır. Bu bağlamda; bölgede yaşanan ve en son 2019 yılında Kırgızistan'ın Batken şehri Maksat köyü yakınlarında meydana gelen anlaşmazlıkta iki devletin cumhurbaşkanları devreye girerek olayları yatıştırmak durumunda kalmışlardır (Isakov, 2019). Fakat 2010-2019 yılları arasında bahsi geçen bölgede yaşanan anlaşmazlıkların bir süreklilik arz ettiği görülmektedir. Ancak Orta Asya genelinde bir güvenlikleştirme konusu olarak ele alındığına dair bir gelişme yaşanmamıştır. Benzer şekilde, 2020'de Dunganların ${ }^{3}$ yoğun olduğu bölgelerden Kazakistan'ın Cambıl eyaleti Masançi kasabasında Kazaklar ile Dunganlar arasında sıradan bir trafik tartışması sonrasında büyüyen olaylar kısa zamanda etnik temelli kitlesel bir çatışmaya evrilmiştir (Independent Türkçe, 2020). Yaşanan çatışmalar nedeniyle, Kazakistan'dan yüzlerce Dunganın Kırgızistan'da Dunganların yoğun olduğu bölgelere göç etmek zorunda kaldığı bilinmektedir (Özşahin, 2020). Örneklerden anlaşılacağı üzere, Orta Asya devletleri arasında iç içe geçmiş etnik nüfus nedeniyle çeşitli tarihlerde ve çeşitli nedenlerle meydana gelen anlaşmazlıklar görülebilmektedir. Ancak bu meseleler hiçbir zaman güvenlikleștirilmediği gibi algılanan tehdidin bertaraf edilmesi yönündeki çalışmalar, anlaşmazlığa taraf etnik kimliğe sahip çıkan devletler arasında ikili faaliyetlerin ötesine geçememektedir. Oysa bir bölgenin Kopenhag Okulu'nun işaret ettiği Bölgesel Güvenlik Kompleksi kapsamında değerlendirilebilmesi için okulun kavramsallaştırdığı güvenlikleştirme politikasının mevcut olması gerekmektedir.

Diğer yandan, Orta Asya zayıf devletlerden ve güçlerden oluşan bir bölge olarak yorumlanmaktadır. Buna gerekçe olarak ise devletlerin etkileşim ve rekabet kapasitesinin düşüklügü öne sürülmektedir. Benzer şekilde, bölgedeki ulusal ve etnik kimlikler de zayıf olarak ele alınmaktadır. Ulusal kimliklerin zayıflığı ile anlatılmak istenen, iç içe geçmiş etnik nüfusları nedeniyle bölge devletlerin uluslaşma yönünde yeterli olamamasından bahsedilmektedir. Etnik kimliklerin zayıflığı ise yine aynı nedenden, yani iç içe geçmiş etnik nüfustan, kaynaklanmaktadır. Bir başka ifadeyle; dağınık halde yaşayan aynı etnik kökene sahip bireyler bölgesel anlamda bir arada politik duruş sergileme kabiliyetinden yoksun oldukları için zayıf olarak nitelendirilmektedir. Ancak ülkesel düzeyde etnik kökenli rekabet yoluyla bölgenin dengelerin gözetildiği anlaşılmaktadır. Bu nedenle, bölgedeki ulusal ve etnik kimliklerin birbiriyle rekabet içinde olması bir zorunluluk şeklinde tarif edilmektedir. Dolayısıyla, bölgede kimlik temelli bir çatışma olasılığı her zaman mevcuttur fakat etnik çatışma olasılığı ulusal çatışma olasıllğından daha düşüktür. Yani etnik meseleler üzerinden iki veya daha çok bölge devletinin doğrudan çatışmaya girdiği durumlar Orta Asya özelinde

${ }^{3} 19$. Yüzyıl'ın sonlarında Çin'den Orta Asya'ya göç eden bir halk olan ve günümüzde Kazakistan ile Kırgızistan sınırları içinde kalan bölgelerde yaşayan Dunganlar hakkında detaylı bilgi için bkz. (Kılıç, 2013). 
mevcut değildir. Bu bağlamda; ülkesel ya da bölgesel düzeyde iç kaynaklı herhangi bir tehdit alg1s1 yoğun şekilde gözlenmemektedir (Buzan ve Wæver, 2003: 423-424)

Kopenhag Okulu'nun Orta Asya özelinde dikkat çektiği bir diğer güvenlik meselesi, sınırlarla ilgilidir. Örneğin; Fergana Vadisi Tacikistan, Kırgızistan ve Özbekistan'ın sınırlarının kesiştiği bir coğrafi alan olup heterojen bir nüfusa sahiptir. Ancak sınırlarla ilgili bir çatışma nadiren görülmektedir (Buzan ve Waver, 2003: 424). Bu durum devletler arasında sınır anlaşmazlıkları olmadığı anlamına gelmemektedir. 1991 yılında SSCB'nin dağılmasıyla bağımsız olan Orta Asya devletleri, çeşitli sınır sorunlarının da öznesi konumunda olmuşlardır. Örneğin; Kazakistan ile Özbekistan arasındaki sınır ihtilaflarının çözümü, en son 10 Kasım 2017 tarihinde imzalanan sınırların kesişme noktalarının ilişkin düzenlemelerle sağlanmıştır (Kırım Haber Ajansı, 2017). Benzer şekilde, Kazakistan ile Türkmenistan arasındaki sınır ihtilafları 18 Nisan 2017 tarihinde sınır belirleme anlaşmasına ilişkin ortak bildiri ile iki devlet arasındaki sınır ihtilafları tamamen çözülmüştür (Kazakistan.KZ, 2017). Kırgızistan ve Özbekistan arasında yaşanan sınır ihtilaflarına ilişkin, iki devlet arasında yaklaşık 1400 kilometrelik sınır hattının \%85'lik kısmının ilgili devletlerce çözüme kavuşturulduğu bilinmektedir (Joldoshov, 2019: 313-315). Kırgızistan ve Tacikistan arasında yaşanan sınır ihtilaflarına ilişkin iki devlet arasındaki çözüm görüşmeleri 2002 yılında başlamış fakat yaklaşık 970 kilometrelik sınırın büyük bir kısmı üzerinde henüz anlaşmaya varılamamıştır (Joldoshov, 2019: 315). Özbekistan ile Tacikistan arasındaki sınır ihtilafina ilişkin müzakereler 2000 yılında başlamış (Joldoshov, 2019: 317) ve 2019 yılında iki devlet liderinin bir araya gelmesiyle müzakerelerin devam ettiği görülmüştür (TASAV, 2019). Özbekistan ile Türkmenistan arasındaki sınır ihtilafi, iki devlet arasındaki kesişen sınır noktalarının 2017 yılında tamamen belirlenmesiyle çözüme kavuşturulmuştur. Sınır meselelerine yönelik bölge devletlerinden Kazakistan ile bölge dışı devletlerden Çin Halk Cumhuriyeti (ÇHC) arasında yaşananları da örnek olarak sunmak mümkündür. Kazakistan'ın bağımsız olduğu daha ilk yıllarda ÇHC ile sınırların belirlenmesine yönelik bir anlaşma yapılmış ve bu konuya yönelik güvenlik tehdidi ortadan kaldırılmıştır (Nazarbayev, 2012a: 226-227). Dolayısıyla "muhtemel çatışma bölgesi" (Nazarbayev, 2012: 226) olarak tanımlanan sınır noktalarında Kazakistan ve ÇHC ikili anlaşma yoluyla bir çözüme gitmiştir. $\mathrm{Bu}$ durum diğer bölge devletleri aralarında yaşanan sınır sorunlarının tamamı için geçerli bir tespittir. Çünkü örneklerde görüldüğü üzere, sınır ihtilafları bağlamında herhangi bir güvenlik meselesinin bölgesel düzeyde değil, tek devlet mantığıyla yani ikili ilişkilerle çözüme kavuşturulduğu görülmektedir. Özetle, sınır meselelerinin de ortak bir güvenlikleştirmeye dahil olmadığı açıktır.

Buzan ve Wæwer, bölgenin uluslararası meselelerine örnek olarak; uyuşturucu trafiğgi, göç, kaçakçılık ve terörizmi örnek vermektedir (2003: 425). Fakat bu meselelerin de ortak bir güvenlikleştirmeye dahil olmadığı görülmektedir. Örneğin; Kazakistan terörizm ile ilgili, kendisini Orta Asya ve Güney Asya bölgelerinde gelişen terörizmden uzak olmak dolayısıyla "kazançlı" olarak yorumlamaktadır. Çünkü terörizmin yaygınlaşmasıyla ilgili eğilimleri ve dinamikleri inceleyebilecek zamana sahip olduğu düşüncesindedir. (Nazarbayev, 2012b: 54). Dolayısıyla, verilen bu düşünceden anlaşılacağı üzere, Kazakistan terörizm konusunda kendisini bölgedeki diğer devletlerden ayırmaktadır. Yani Kazakistan, Orta Asya'da terörizm konusunu güvenlikleştirmek için kendisine bir çeşit görev atfetmektedir. Bu görev terörizm eğilimlerini ve dinamiklerini inceleyebilecek şekilde "kazançlı" olduğuna yönelik söylem ile kendini göstermektedir. Dolayısıyla, bir meselenin güvenlikleştirilme sürecine ilişkin söylem ve gündem oluşturma safhasını karşılamaktadır. Ancak diğer devletlerin meseleyi Kazakistan ile aynı düzeyde güvenlikleştirmedikleri herhangi bir bölgesel girişimde bulunmayışlarından anlaşılmaktadır. 
Orta Asya devletlerinden Özbekistan'ın yukarıda bahsi geçen çeșitli konularda, bölge devletleriyle kıyaslandığında daha çatışmacı bir tutum sergilediği görülmektedir. " $\mathrm{Bu}$ kapsamda bölge ülkeleri arasında sınır sorunlarının, etnik çatışmaların ve radikalizmin iç içe ve en derin yaşandığı iki ülke Kırgızistan ve Özbekistan'dır.” (Birdişli, 2017: 127). Ayrıca Tacikistan ile Özbekistan arasında geleneksel bir düşmanlık algısı mevcuttur (Birdişli, 2017: 127). Bir başka ifadeyle, iki devlet arasında gerek SSCB döneminde gerekse bağımsızlık sonrasında su, enerji, ayrılıkçı hareketler ve radikal örgütlenmeler gibi konularda günümüzde çözüme kavuşturulmamış meseleler bulunmaktadır (Demirci, 2012: 61; Kafkasyalı ve Tacibayev, 2012: 252-253). Bu noktada, bölgesel güvenlik kompleksinin önermesine uygun şekilde, Özbekistan'ın diğer devletleri dost olarak tanımlaması bir gereklilik arz etmese de düşmanlık algısı herhangi bir meselenin ortak güvenlikleştirilmesine engel olabilmektedir. Benzer şekilde Kazakistan ile Özbekistan arasında Orta Asya'da "Bölgesel Güç" olmak yönünde bir rekabet söz konusudur. Bu rekabeti, "Bölgesel Güç" çalışmalarında, bir devletin bölgesel güç olabilmek için gerekli ön şartlarından olan "bölgesel güç olma konusunda iddialı olmak" durumu üzerinden açıklamak mümkündür. Akkaya'nın konuya ilişkin çalışmasında, Özbekistan askeri gücüne, doğal kaynaklarına ve politika kültürüne dayanarak "uzlaşmasız" bir tavır sergilediği üzerinde durulmaktadır. Bu durum ise Özbekistan'1 bölgesel güç olma yönünde iddialı bir Orta Asya devleti olduğu yönünde bir tespiti beraberinde getirmektedir. Bu bağlamda; Kazakistan bölgesel güç olmak için bölgeden kabul görme ön şartının farkında olarak yumuşak güce ağıllık verse de Özbekistan sert güç yaklaşımıyla hareket etmektedir (Alpaslan, 2011: 477; Efegil, 2010: 54-55; Akkaya, 2018: 84-85). Bu durum ise meselelerin, Özbekistan kaynaklı olarak, bölgesel düzeyde güvenlikleştirilmesini zorlaştıran bir diğer etkendir.

Orta Asya bölgesinin diğer bölgelerle etkileşimi oldukça zayıftır. İşbirliği kaynaklı örgütlenmelerde Kazakistan dışındaki devletlerin oldukça pasif bir rol oynadığ görülmektedir. Askeri işbirliği özelinde düşünülecek olursa, Türkmenistan halihazırda "tarafsız devlet" statüsündedir. Diğer devletlerin ise askeri çapta diğer bölgelerle bir örgütlenme içinde olmadıkları bilinmektedir. Bu durum diğer bölgelerle hiçbir etkileşimde bulunmadıkları anlamına gelmemekle birlikte ortak güvenlikleştirme bağlamında gerek bölgesel gerekse başka herhangi bir düzeyde girişimin olmadığına işaret etmektedir.

Küresel güçlerin bölgedeki rolleri de bölge devletleri bağlamında farklılık göstermektedir. Örneğin; Rusya Federasyonu (RF) ile Kazakistan'ın ikili ilişkileri diğer bölge devletlerine kıyasla üst düzeydedir. Bu durumun en önemli etkenlerinden bir tanesi Kazakistan'da yaşayan Rus kökenli vatandaşlardır ${ }^{4}$. Bir diğer etken ise iki devletin sınır paylaşıyor olmasından kaynaklanmaktadır. Ancak RF ile bölgedeki diğer devletlerin aynı düzeyde ilişkilere sahip olduğunu belirtmek güçtür. ÇHC ile bölge devletlerinin tümünde özellikle ekonomi alanında bağımlılık derecesinde ilişkiler mevcuttur. ÇHC'nin enerji ihtiyacı ise bölgeyle olan ilişkilerini düzenleyen önemli başlıklardan bir tanesidir. Örneğin; ÇHC Tacikistan'ın ihracat yaptığı ülkeler listesinde yaklaşı \%18'lik bir pay ile ikinci sırada iken ithalat yaptığı ülkeler arasında yaklaşık \%9'luk bir pay ile üçüncü sıradadır. Kırgızistan ihracat yaptığı ülkeler listesinde ÇHC yer almazken ithalat yaptığı ülkeler listesinde yaklaşık \%33'lük bir pay ile ilk sırada yer almaktadır. Türkmenistan ile ÇHC arasındaki ekonomik ilişkiye bakıldığında, ÇHC Türkmeninstan'ın ithalat listesinde toplam ithalatın yaklaşık

\footnotetext{
${ }^{4} 2019$ verilerine göre yaklaşık 19 milyon kişinin yaşadığı Kazakistan'da nüfusun yaklaşık \%19'unu Rus kökenli vatandaşlar oluşturmaktadır. Bu yönüyle Rus kökenli vatandaşlar, Kazakistan'da Kazaklardan sonra en çok nüfusa sahip ikinci etnik gruptur. Diğer Orta Asya devletlerinde yaşayan Rus kökenli vatandaşlar ile karşılaştırıldığında, Kazakistan'da yaşayan Rus kökenli vatandaşların toplamı diğer Orta Asya devletlerinde yaşayan Rus kökenli vatandaşların toplamından daha fazladır. Konuya ilişkin detaylı istatistiksel bilgiler için bkz. (Central Intelligence Agency-CIA).
} 
\%84'lük bir kısmını toplam ihracatın ise yaklaşık \%9'luk bir kısmını elinde bulundurmaktadır. Kazakistan ekonomisinde ÇHC, ihracat açısından yaklaşı \%12'lik bir oranla ihracat açısından ise yaklaşık \%16'lık bir oranla yer almaktadır. Son olarak, Özbekistan ile ÇHC'nin ekonomik ilişkilerine bakıldığında ise Özbekistan'ın ihracat yaptığı ülkeler arasında ÇHC'nin \%15,5'lik bir paya sahip olduğu ithalat yaptığı ülkeler arasında yaklaşık \%24'lük bir pay ile ilk sırada yer aldığı görülmektedir (Central Intellingence Agency-CIA). Bu bilgiler 1şı̆̆ında, Orta Asya devletleri ile ÇHC arasındaki ekonomik ilişkilerin oldukça önemli seviyede olduğu açıktır. Amerika Birleşik Devletleri (ABD)'nin bölge devletleriyle ilişkisi ise genellikle askeri düzeyde seyretmektedir. Birdişli'ye göre, Orta Asya'nın ABD açısından önemi ÇHC'ye komşuluğunu yanı sıra Afganistan ve İran'a yakınlığından kaynaklanmaktadır. Dolayısıyla, Orta Asya ABD açısından askeri anlamda stratejik bir konuma sahiptir (2019: 300). ABD'nin bölgede varlık gösterme kaygısı, onu farklı zamanlarda farklı Orta Asya devletleri ile yakın ilişkilere yönlendirmektedir. Örneğin; 11 Eylül 2001'de ABD'de meydana gelen terör eylemleri sonrasında ABD, Özbekistan'da yer alan havalimanlarını Afganistan müdahalesi kullanma talebinde bulunmuş ve olumlu yanıt almıştır. Aynı yıl Kırgızistan ve Tacikistan'dan da benzer bir talepte bulunmuş ve olumlu yanıt almıştır. 2002'de ise Kazakistan ile ancak acil inişler için Almatı havalimanının kullanımı amacıyla olumlu yanıt alabilmiştir. 2004-2008 yılları arasındaki dönemde ise Özbekistan ve Tacikistan, bölgede meydana gelen "Renkli Devrimler" nedeniyle daha mesafeli bir duruş sergilemiştir. Ancak bu dönem özelinde Kazakistan'ın ABD'yle ilişkilerini değiştiren bir politikaya yer vermediği görülmektedir (Suyundikov, 2020). Dolayısıyla, bölge devletlerinin küresel güçlerden üç tanesi ile ilişkileri incelendiğinde genellikle bölgesel bir seyir izlemedikleri, aksine gelişen koşullar karşısında ayrı ayrı politikalar yürüttükleri görülmektedir. Bu bağlamda; ortak bir güvenlikleştirme durumu söz konusu değildir.

Orta Asya'da, yukarıda verildiği üzere, birçok farklı konuda sorunların mevcut olduğu açıktır. Fakat bu sorunlar bölgede, istisnalar dışında, yüksek gerilim ve büyük çatışmalara neden olmamaktadır. Ancak devletlerin görece yeni kurulmuş olmaları onları çeşitli kademelerde olsalar da zayıf ve pasif bir uluslararası siyasete zorlamaktadır. Etkileşim yönünden zayıf ve pasif olmaları ise ortak güvenlik kaygıları olsa dahi bu kaygıları ortak bir zeminde güvenlikleştiremedikleri için Orta Asya'nın bir bölgesel güvenlik kompleksi olarak tanımlanmasını güçleştirmektedir. Rüştü Kaya (2019), yukarıda verilen bilgiler nedeniyle esasında Orta Asya'yı bir güvenlik kompleksi olarak tanımlanması gerektiğini işaret etmektedir. Kaya'ya göre; bölge devletlerinin ortak değerlere sahip olmaları ve herhangi bir konuda işbirliği potansiyeline sahip olmaları onları bölgesel güvenlik kompleksi olarak tanımlamak için yeterli görülmektedir. Bu bağlamda; çalışmasında Orta Asya'yı bir bölgesel güvenlik kompleksi olarak ele almıştır. Fakat bölge devletlerinin ortak değerlere sahip olmasına rağmen bu değerler üzerinden herhangi bir tehdit algısıyla ortak güvenlikleştirme sürecinde olmadıkları için bu tespit tartışmaya açıktır.

Orta Asya'nın bölgesel güvenlik kompleksi olarak tanımlanıp tanımlanamayacağı henüz bir soru işareti olarak varlığını sürdürmektedir. Çünkü bölge devletlerinin her birinin kendine özgü ya da iç kaynaklı tehdit potansiyelleri vardır. Örneğin; Özbekistan, Kırgızistan ve Tacikistan ülke içi radikal unsurlar ile sürekli mücadele halindedir. Kazakistan'daki Rus kökenli vatandaşların nüfus olarak oldukça yüksek seviyede olması, yönetim açısından bir tehdit unsurudur. Benzer şekilde, Orta Asya devletlerinin tümünde demokratik yönetimlerin gelişmemiş olması yönetim değişikliklerinin demokratik olmayan yollarla sağlanmasına neden olmaktadır. Kırgızistan'ın yönetiminin 2010 yılında demokratik olmayan yollar ile değişmesi bu durumun en somut örneklerinden biridir. Fakat bu gibi meselelerin hiçbiri bölgesel bağlamda ortak güvenlikleştirme girişimlerine neden olmamıştır. Bölgedeki 
devletlerin birbirleriyle olan ilişkilerinde ikili ilișkiler ön plandadır. Bölgesel düzeyde bir iletişim tercih edilmediği için meselelerin güvenlikleştirilmesi de güçleşmektedir. Bölgenin diğer bölgelerle etkileşim düzeyi yine bölge devletlerinin ikili ilişkileri bağlamında ilerlemektedir. $\mathrm{Bu}$ yönüyle bölgesel bütünsellikten uzak, pasif bir tutum sergilenmektedir. Benzer şekilde, küresel güçler ile bölge devletlerinin ilişkileri de ikili düzeyde devam etmektedir. Tüm bu gerekçelerle, Orta Asya'nın birçok konuda ortak zeminde buluşabileceği fakat bölgesellikten uzak tutum sergilemeleri nedeniyle halihazırda bölgesel güvenlik kompleksi oluşturamadıkları açıktır. Fakat yüksek potansiyele sahip olmasına rağmen, bölge devletleri arasında keskin düşmanlıklar görülmemesi devletlerin gelişimine paralel olarak bir bölgesel güvenlik kompleksi oluşabileceği izlenimi vermektedir. Dolayısıyla, Orta Asya'nın bölgesel güvenlik kompleksi bağlamında en doğru tespit yine Buzan ve Wæver (2003: 423) tarafından sunulmaktadır. Buna göre; Orta Asya, Rus etkisinin görüldüğü zayıf bir "alt kompleks" olarak sınıflandırılmaktadır. Ancak Sovyet sonrası coğrafyadan ayrı bir bölgesel güvenlik kompleksi adayı olarak kabul edilebilir. Bu noktada; "alt kompleks" kavramı ile ne anlatılmak istendiği önem kazanmaktadır.

Buzan ve Wæver, bölgesel güvenlik kompleksini birçok açıdan detaylandırdıkları çalışmalarında bölgesel güvenlik komplekslerinin kapsadığı daha küçük bölgeleri alt kompleksler olarak ele almaktadır. Bu alt kompleksler, bölgesel komplekslerle aynı tanım ve özelliklere sahip olmakla birlikte kendilerinden daha büyük bir kompleksin içine "sıkıca gömülmüş" olmaları dolayısıyla farklılaşmaktadır. Bu yönüyle alt komplekslerin "yarım seviye" bölgesel güvenlik kompleksleri oldukları belirtilmektedir (2003: 51). Dolayısıyla herhangi bir alt komplekse üye devletlerin güvenlik algılarını ortaklaştırabildikleri ve bu ortaklığ belirtmek mümkündür. Bu noktada, Orta Asya'da ortaklaşmanın nasıl sağlanabileceği sorusu önem kazanmaktadır. En önemli koşullardan bir tanesi, bölge devletlerinin siyasal ve ekonomik dıș bağımlılığını azaltmasıdır. Bunun için alt komplekste yer alan her devletin kalkınma programı belirlemesi gibi ortak bir kalkınma programının da belirlenmesi yerinde olacaktır. Daha önce belirtildiği üzere, bölgede çözülmesi imkansız ve ortaklığı engelleyecek düzeyde ciddi çatışmalar yaşanmamaktadır. Bu durumun devamlılığı sağlanmalı ve küçük çaplı olumsuzluklar ortak hareket edilerek çözüme kavuşturulmalıdır. Böylelikle aktörler, ortak hareket edildiği takdirde sorunların çözüleceğini deneyimleme firsatı bulacaktır. Ayrıca Orta Asya'da en az bir bölgesel güce ihtiyaç olduğu açıktır. Detaylandırmak gerekirse, bölgede varlık gösterecek bir ya da birden çok bölgesel güç, bölge devletlerini herhangi bir konuda bölgedeki önemi dolayısıyla yönlendirebilecektir. Bu bağlamda; Orta Asya devletlerinden herhangi bir devletlin ya da devletlerin bölgesel güç olarak görülmesi, bölgesel düzeyde bir mesele var ise bu meselenin güvenlikleştirilmesi ve bölgesel düzeyde çözüm aranması konusunda teşvik edici bir etkiye sahip olacaktır. Bu açıdan bölgesel güç olma ihtimali en yüksek aday Kazakistan olup ikincisi Özbekistan'dır. Bölgesel güç ya da güçler vasıtasıyla bölgenin küresel bağlamda görünürlüğü de artacaktır. Bu durum ise bölge devletlerinin birçok konuda yekvücut bir şekilde hareket etmesine imkan tanıyacaktır. Bölge devletlerinin büyük güçler ile ikili ilişkilerinde de ortak bir duruş sergileyerek mesafeli olmaları gerekmektedir. Orta Asya'nın bahsi geçen konularda göstereceği her türlü gelişme bölgenin bir güvenlik kompleksi olarak ele alınmasını kolaylaştıracaktır. Nihayetinde bölge devletlerinin ortak tehdit algılarına karşı daha bağımsız bir şekilde ve ortak hareket ettikleri bir alan oluşacaktır. Bir başka ifadeyle, yakın coğrafyada güvenli bir alan oluşturma imkanı doğacaktır. Bu gelişmeler yaşanana kadar ise Orta Asya, bir "yarım seviye" bölgesel güvenlik kompleksi ya da alt güvenlik kompleksi olarak varlık göstermeye devam edecektir.

\section{Sonuc}


Uluslararası ilișkiler disiplinin en önemli sorunlarından biri olan güvenlik II. Dünya Savaşı'ndan itibaren akademik anlamda çalışılan bir konu haline gelmiştir. Bu bağlamda; Soğuk Savaş'ın son yıllarından itibaren yaşanan değişimle birlikte güvenlik çalışmalarında da niteliksel ve niceliksel değişimler yaşanmaktadır. Dolayısıyla, Soğuk Savaş döneminde hakim olan geleneksel realist bakış açısından farklı seçeneklerin ortaya çıktığı görülmektedir. Kopenhag Okulu, güvenlik çalışmalarına farklı bir bakış açısı getiren önemli araştırma okullarından bir tanesi olarak göze çarpmaktadır. Bu anlamda okulun özellikle "Güvenlikleştirme", "Güvenlik Sektörleri” ve "Bölgesel Güvenlik Kompleksi” yaklaşımları ile güvenlik çalışmalarına katkıda bulundukları görülmektedir.

Kopenhag Okulu, "Bölgesel Güvenlik Kompleksi” yaklaşımı ile dünyayı farklı bölgelere ayırmaktadır. Bu ayrım yapılırken coğrafi yakınlığın yanı sıra herhangi bir ya da birçok ortak değere sahip olma durumu, bir bölgenin güvenlik kompleksi olabilmesi için gerekli ön şartlar arasında yer almaktadır. Ayrıca ele alınan bölge devletlerinden, herhangi bir ya da birçok meseleyi ortak bir şekilde güvenlikleştirmeleri beklenmektedir. Bu meseleler ise yalnızca askeri meseleler ile sınırlı olmayıp "Güvenlik Sektörleri” yaklaşımında ele alınan sektörleri de kapsamaktadır. Bu kapsamda; Kopenhag Okulu'nun bölgesel güvenlik kompleksi olarak değerlendirdikleri bölgelerden bir tanesi Sovyet sonrası coğrafya olarak tarif edilmektedir. Dolayısıyla, okulun çalışmaları incelendiğinde Orta Asya ele alınırken Sovyet sonrası coğrafya bölgesel güvenlik kompleksi kapsamında değerlendirildiği görülmektedir.

$\mathrm{Bu}$ çalışmada, Kopenhag Okulu'nun Sovyet sonrası coğrafya bölgesel güvenlik kompleksi olarak tarif ettiği alanda Orta Asya'nın bir alt kompleks olarak yer alması sorgulanmıştır. Bu bağlamda; Orta Asya bağımsız bir bölgesel güvenlik kompleksi olabilir mi sorusu üzerinden bir değerlendirme yapılmıştır. Bunun ana nedenlerinden bir tanesi, Sovyet sonrası coğrafyanın niteliksel ve niceliksel anlamda çok geniş ve farklılıklara sahip bir coğrafyayı tarif ediyor olmasıdır. Diğer yandan Orta Asya devletlerinin tamamının benzer siyasal, ekonomik, sosyo-kültürel vb. konular üzerinde ortak değerlere sahip olduğu tespitinde bulunulmaktadır. Ancak Orta Asya'da devletlerin görece "genç" ve "zayıf" devletler olmaları, bölge içinde ve dışında pasif siyaset sergilemeleri, bir ya da birden çok bölgesel güce sahip olmamaları ve bölge dışında çeşitli açılardan bağımlılığa sahip olmaları vb. konular ortak hareket etmelerine engel olmaktadır. Bir başka ifadeyle; bahsi geçen nedenlerle herhangi bir meseleyi ortak bir şekilde güvenlikleştiremedikleri görülmektedir. Dolayısıyla, Orta Asya bir bölgesel güvenlik kompleksi olmasa da bölgesel güvenlik kompleksi olmaya aday olduğu belirtilmiştir.

Kopenhag Okulu, alt kompleks ya da bölgesel güvenlik kompleksi olmaya aday bölgeler için yeterli bir analiz sunmamaktadır. Bu çalışma, bir bölgesel güvenlik kompleksi adayı olarak Orta Asya'nın adaylığını olumlu şekilde sonlandırmak için gerekli olan uygulamaları belirleme noktasında güvenlik çalışmalarına katkı sunmaktadır. Buna göre; öncelikle, bölge devletlerinin siyasal ve ekonomik olarak dış bağımlılıklarını azaltmaları gerekmektedir. Bunun için bölge devletlerinin bağımsız kalkınma programları yanı sıra bölgesel kalkınma programlarına da ihtiyaç duydukları açıktır. Ayrıca bölgede çözülmesi imkansız çatışmaların olmayışı önemli bir firsattır. Bu durumun devamlılığı sağlanmalı ve gelecekteki olası anlaşmazlıklar ortak akıl yoluyla çözüme kavuşturulmalıdır. Böylelikle aktörler ortak hareket ettikleri takdirde sorunların çözüme kavuştuğunu deneyimleme fırsatı bulacaktır. Bir diğer konu Orta Asya'nın "Bölgesel Güç" ihtiyacıdır. Orta Asya'da Kazakistan ve Özbekistan olmak üzere bölgesel güç olma potansiyeline sahip iki devlet mevcuttur. Bölgesel güç ya da güçler vasitasıyla bölgenin küresel bağlamda temsilinin ve görünürlüğünün artması mümkündür. Yekvücut hareket edilmesi gereken durumlarda bu harekete imkan tanıyacak bir yaklaşım Orta Asya'nın bölgesel güvenlik kompleksi adaylığı 
aşamasında önemlidir. Buna paralel olarak; bölge devletleri "büyük güçler" ile ikili ilişkilerinde de ortak bir duruş sergileyerek bağımlılıklarını azaltma yoluna gitmelidir. Belirtilen öneriler uygulandığı takdirde Orta Asya'da bir bölgesel güvenlik kompleksi ve görece daha güvenli bir alan oluşacaktır. 


\section{Kaynakça}

AKGÜL AÇIKMEŞE, S. (2018). Güvenlik, Güvenlik Çalışmaları ve Güvenlikleştirme. E. Balta (Ed.), Küresel Siyasete Giriş: Uluslararası İlişkilerde Kavramlar, Teoriler, Süreçler içinde (s. 241-257). İstanbul: İletişism Yay.

AKINER, S. (1997). Central Asia: Conflict or Stability and Development?. An MRG International Report, 96 (6), Minority Rights Group.

AKKAYA, C. (2018). Kazakistan Orta Asya'da Bir "Bölgesel Güç" Müdür?. Yayınlanmamış Yüksek Lisans Tezi, Aydın: Adnan Menderes Üniversitesi.

ALPASLAN, M. (2011). Kazakistan Cumhuriyeti Siyasi Gelişmeler (1991-2010). İyikan, N., (Ed.), Orta Asya-Güney Kafkasya 1991-2010 içinde (442-490), İstanbul: Hiperlink Yayınları.

AYDIN, M. (2004). Kafkasya ve Orta Asya ile İlişkiler: Yeni Jeopolitik Bölge, Yeni Terminoloji (Bilgi Kutusu). Oran, B., (Editör), Türk Dış Politikası: Kurtuluş Savaşından Bugüne Olgular, Belgeler, Yorumlar içinde (366-440), (Cilt 2:1980-2001), (7. Bask1). İstanbul: İletişim Yay.

AYDIN, M. (2017). Kafkasya ve Orta Asya ile İlişkiler. Oran, B., (Editör), Türk Dış Politikası: Kurtuluş Savaşından Bugüne Olgular, Belgeler, Yorumlar içinde (463-532), (Cilt 3:2001-2012), (3. Bask1). İstanbul: İletişim Yay.

BAYSAL, B. ve LÜLECİ, Ç. (2015). Kopenhag Okulu ve Güvenlikleştirme Teorisi. Güvenlik Stratejileri, 11 (22), 61-96.

BECK, M. (2010). Israel: Regional Politics in a Highly Fragmented Region. Flemes, D., (Ed.), Regional Leadership in the Global System: Ideas, Interests and Strategies of Regional Powers içinde (127-151). Surrey: Ashgate Publishing.

BUZAN, B. (1983). People, States, and Fear: The National Security Problem in International Relations. Brington: Wheatsheaf Books.

BUZAN, B. ve WÆVER, O. (2003). Regions and Powers: The Structure of International Security. New York: Cambridge University Press.

BUZAN, B. vd. (1998). Security: A New Framework for Analysis. London: Lynne Rienner Publishers.

BİLGİN, P. (2010). Güvenlik Çalışmalarında Yeni Açılımlar: Yeni Güvenlik Yaklaşımları. Stratejik Araştırmalar, Ocak, 8 (14), 30-53.

BİRDİŞLI, F. (2017). Orta Asya Bölgesel Güvenlik Kompleksi Bağlamında KırgızistanÖzbekistan İhtilafı. Yönetim Bilimleri Dergisi, 15 (30), 123-143.

BİRDİȘLI, F. (2019). Teori ve Pratikte Uluslararası Güvenlik: Kavram-Teori-Uygulama. (Güncellenmiş 4. Baskı), Ankara: Seçkin Yay.

BREZEZINSKI, Z. (2005). Büyük Satranç Tahtası: Amerika'nın Küresel Üstünlüğü ve Bunun Jeostratejik Gereklilikleri. (Çev: Yelda Türedi). İstanbul: İnkılap Yay.

CENTRAL INTELLIGENCE AGENCY-CIA. The World Factbook. https://www.cia.gov/library/publications/resources/the-world-factbook/, Erişim Tarihi: 16.12.2020. 
DEMIRCİ, L. (2012). Özbekistan, Kırgızistan ve Tacikistan'ın Kesişimindeki Sorunlu Vadi: Fergana. Savunma Bilimleri Dergisi, 11 (2), 33-69.

DW.COM. (2005). Özbekistan'da Aşırı İslamcı Ayaklanma. (13.05.2005). https://www.dw.com/tr/\%C3\%B6zbekistanda-a\%C5\%9F\%C4\%B1r\%C4\%B1islamc\%C4\%B1-ayaklanma/a-2524915, Erişim Tarihi: 08.12.2020.

EFEGiL, E. (2010). Orta Asya Devletlerinin Dış Politikasını Belirleyen Temel Faktörler: Rejim Güvenliğine Karşı Yayılmacı Politik Rekabet. Arı, T., (Editör), Orta Asya ve Kafkasya: Rekabetten İşbirliğine içinde (41-64). Bursa: MKM Yayıncılık.

FLEMES, D. (2007). Conceptualising Regional Power in International Relations: Lessons from the South African Case. German Institute of Global and Area Studies, (Ed.), Hamburg: German Institute of Global and Area Studies.

HURRELL, A. (2005). Hegemony and Regional Power Governance in the Americas. Fawcett, L. ve Serrano, M., (Ed.), Regionalism and Governance in the Americas: Continental Drift içinde (185-207). New York: Palgrave Macmillan.

INDEPENDENT TÜRKÇE. (2020). Kazaklarla Dunganlar Arasında Kavga: 10 Ölü, 165 Yarall. $\quad 09.02 .2020 . \quad$ https://www.indyturk.com/node/129831/d\%C3\%BCnya/kazaklarladunganlar-aras\%C4\%B1nda-kavga-10-\%C3\%B61\%C3\%BC-165-yaral\%C4\%B1, Erişim Tarihi: 08.12.2020.

ISAKOV, A. (2019). Kirgizistan-Tacikistan Sinırında Tirmanan Gerilim. 19.09.2019. https://ankasam.org/kirgizistan-tacikistan-sinirinda-tirmanan-gerilim/, Erişim Tarihi: 08.12.2020.

JOLDOSHOV, A. (2019). Kimlik ve Sınır: Orta Asya'da Sınır Sorunları. Türk Dünyası Incelemeleri Dergisi, 19 (2), 303-326.

KAFKASYALI, M. S. Ve TACIBAYEV. (2012). Tacikistan: kurgusal Kurtuluştan Kurgusal Politikalara. Türk Dünyası İncelemeleri Dergisi, XII (1), 239-266.

KAPPEL, R. (2014). Israel: The Partial Regional Power in the Middle East. Henner Fürtig, (Ed.), Regional Powers in the Middle East içinde (145-161). New York: St. Martines Press.

KAYA, R. (2019). Orta Asya ‘Bölgesel Güvenlik Kompleksi’ ve Şangay İşbirliği Örgütü. Uluslararası Siyaset Bilimi ve Kentsel Araştırmalar Dergisi, 7 (Özel Sayı), 53-71.

KAZAKISTAN.KZ. (2017). Astana ve Aşkabat, Orta Asya'da Bir Illki Gerçekleştirdi. 18.04.2020. http://www.kazakistan.kz/astana-ve-askabat-orta-asyada-bir-ilki-gerceklestirdi/, Erişim Tarihi: 13.12.2020.

KILIÇ, F. (2013). Kırgızistan'daki Dunganlar: Tarihleri, Göçleri, Yaşamları, Dil Durumları. TürkBilig, 26, 1-26.

KIRIM HABER AJANSI. (2017). Kazakistan-Türkmenistan-Özbekistan Arasında Sinır Anlaşması Imzalandl. $\quad$ 10.11.2017. http://old.qha.com.ua/tr/turkdunyasi/kazakistanturkmenistanozbekistan-arasinda-sinir-anlasmasi-imzalandi/161666/, Erişim Tarihi: 13.12.2020.

LIMA, M. R. S. D. ve HIRST, M. (2006). Brazil as an Intermediate State and Regional Power: Action, Choice and Responsibilities. International Affairs (Royal Institute of International Affairs 1944-), 82 (1), 21-40. 
McDONALD, M. (2008). Constructivism. P. D. Williams (Ed.), Security Studies: An Introduction içinde (s. 59-72). New York: Routledge.

NAZARBAYEV, N. (2012a). Yüzyıllar Kavşağında. (Red. Zafer Kibar). Ankara: SFN Televizyon Tanıtım Yay.

NAZARBAYEV, N. (2012b). Kritik On Yll. (Red. Zafer Kibar). Ankara: SFN Televizyon Tanitim Yay.

NEL, P. ve NOLTE, D. (2010). Introduction: Special Section on Regional Powers in a Changing Global Order. Review of International Studies, 36 (4), 877-879.

NEUMANN, I. B. (1992). Regional Great Powers in International Politics. New York: St. Martin's Press.

NOLTE, D. (2010). How to Compare Regional Powers: Analytical Concepts and Research Topics. Review of International Studies, 36 (4), 881-901.

ÖZŞAHIN, M. C. (2020). Dungan Hadiseleri ve Orta Asya'daki Etnik Fay Hatlart. 14.02.2020. https://www.aa.com.tr/tr/analiz/dungan-hadiseleri-ve-orta-asya-daki-etnik-fayhatlari/1733969, Erişim Tarihi: 08.12.2020.

PURTAŞ, F. (2008). Orta Asya'nın Bütünlüğü Sorunsalı ve Orta Asya'da Bölgesel Entegrasyon Girişimleri. Demirtepe, M. T., (Ed.), Orta Asya \& Kafkasya Güç Politikası içinde 31-62. Ankara: USAK Yay.

ROY, O. (2000). Yeni Orta Asya ya da Ulusların Imal Edilişi. (Çev: Mehmet Moralı). İstanbul: Metis Yay.

SUYUNDIKOV, S. (2020). ABD'nin Orta Asya Politikalart. 02.07.2020. https://www.21yyte.org/tr/merkezler/bolgesel-arastirma-merkezleri/orta-asya-arastirmalarimerkezi/abd-nin-orta-asya-politikalari, Erişim Tarihi: 16.12.2020.

SPEKTOR, M. (2009). Brazil as a Regional Power and Emerging Global Power. South African Institute of International Affairs-Emerging Powers Programme, Policy Briefing 9, 14.

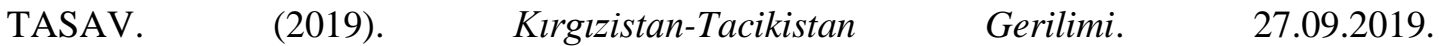
https://www.tasav.org/index.php/kirgizistan-tacikistan-gerilimi-2.html, Erişim Tarihi: 13.12.2020.

WÆVER, O. (1995). Securitization and Desecuritization. R. D. Lipschutz (Ed.), On Security içinde (Chapter 3), New York: Columbia University Press.

YAPICI, U. (2004). Küresel Süreçte Türk Dış Politikasının Yeni Açılımları Orta Asya ve Kafkasya. İstanbul: Otopsi Yay. 